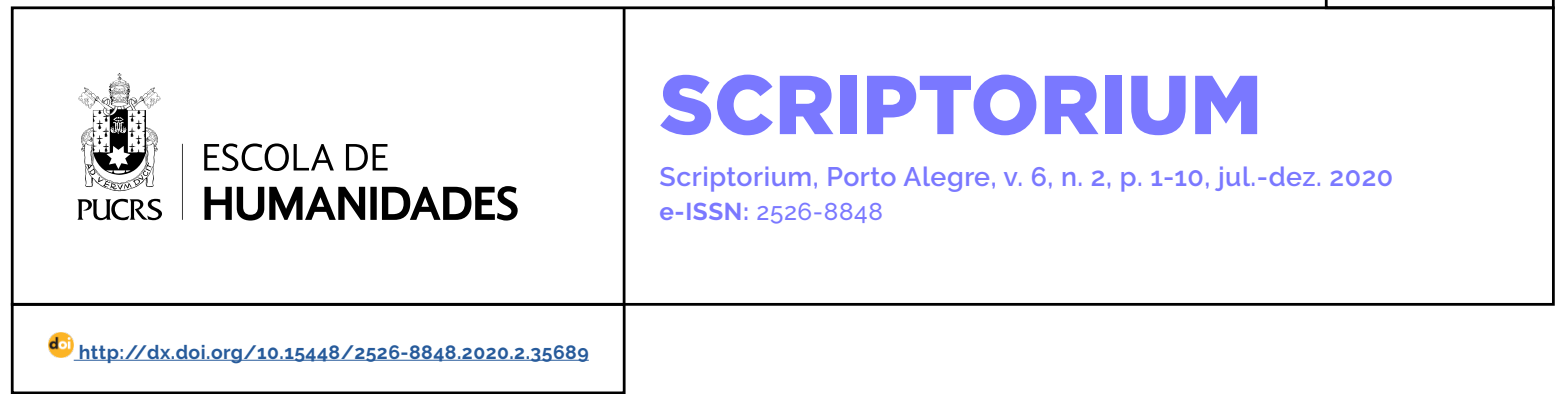

SEÇÃO: TEMATHIS

\title{
Poesia, música e algumas reflexões geográficas
}

Poetry, music and some geographic thoughts

\section{Gabriel Eduardo \\ Bortulini ${ }^{1}$}

orcid.org/0000-0003-4738-7612

gabrielbortulini@gmail.com

Recebido em: 15/08/2019

Aprovado em: 27/04/2021.

Publicado em: 22/09/2021.

\section{(c) (1)}

Artigo está licenciado sob forma de uma licença Creative Commons Atribuição 4.0 Internacional.
Resumo: O presente ensaio busca refletir as noções de poesia e música a partir de uma poética autoral. Dessa forma, a partir de exemplos de poemas de autoria própria, busco discutir algumas noções de musicalidade, ritmo e oralidade na criação poética inserida no que entendo como imaginário do Pampa. A partir desse espaço geográfico, procuro discutir a influência da música, em especial, da milonga, nos versos produzidos nesse mesmo contexto, com foco na payada. Poesia e música, dessa forma, são duas artes quase sempre indissociáveis e que se amparam na oralidade para a criação poética. Com isso, destaca-se a importância do idioma nesse espaço de fronteira, em que o português e o espanhol convivem e dão caráter ao cancioneiro pampeano.

Palavras-chave: Poesia. Música. Pampa. Payada. Milonga.

Abstract: this essay seeks to think the notions of poetry and music from my own poetics. Thus, from examples of poems of my own authorship, I seek to discuss some notions of musicality, rhythm and orality in the poetic creation inserted in what I understand as the pampa's imaginary. From this geographical space, I try to discuss the influence of music, especially the milonga, in the verses produced in this same context, focusing on the form known as payada. Poetry and music, thus, are two forms that are almost always inseparable and based on orality. Therefore, we highlight the importance of language in this border space, where Portuguese and Spanish live and give character to the music and poetry of the Pampa. Keywords: Poetry. Music. Pampa. Payada. Milonga.

\section{Introdução}

"Aqui me pongo a cantar / al compás de la vigüela".

(José Hernández)

Assim, com os versos de José Hernández, inicio este ensaio. Pois, para mim, a poesia é isso: um cantar ao compasso próprio.

Interessei-me por poesia por causa do ritmo. E hoje busco no ritmo uma literatura com caracteristicas sinestésicas: desejo, com as palavras, produziro mesmo efeito que a milonga causa em mim. Busco a planície em meus versos.

Em primeiro lugar, concordo com a afirmação de Siegfried J. Schmidt (1996, p. 119), de que a história é uma construção e não uma reconstrução. Essa construção responde a determinadas necessidades do historiador (políticas, econômicas, sociais, identitárias). Pensar na história do ponto de vista construtivista, porém, não significa que ela seja uma mentira. Apesar disso, trata-se de uma questão dificil de se resolver. Pois a 
"realidade" só pode existir em um plano alheio às mentalidades. Ao mesmo tempo, contudo, os aspectos históricos, ordenados pelo intelecto de um historiador, existem, ou melhor, coexistem, de maneira sistemática e não linear.

É inadequado, assim, pensar a poesia e a música do espaço pampeano de forma individual, visto que ambas se tornariam objetos diferentes. Além disso, esse aspecto musical e literário não existe fora do âmbito geográfico, político, social, econômico, de gênero.

A partir disso, abro este ensaio discutindo poesia e música, apresentando minhas ideias sinestésicas sobre literatura, milonga e pampa. Em um segundo momento, abordarei ritmo e oralidade, esboçando algumas notas sobre payada e a busca pela oralidade. Para finalizar, tratarei sobre a relação do ritmo com a língua, refletindo sobre a necessidade momentânea de nos apoiarmos em um idioma estrangeiro para expressar uma ideia.

Trago, no decorrer do texto, dois poemas de autoria própria, no intuito de refletir sobre a criação poética.

\section{Poesia e música}

Ao propor um ensaio sobre poesia e ritmo, não vejo outra maneira a não ser falar da minha própria experiência. E, com isso, não pretendo afirmar que ela seja vasta: tanto em música como em poesia, sou amador. Isso, no entanto, não impede que eu reflita sobre o fazer poético - e, ao refletir, poderei, talvez, aprimorá-lo. Lembro o que disse Elliot:

Quando ele [o poeta] teoriza sobre criação poética, há probabilidades de que ele esteja generalizando um tipo de experiência; quando ele se aventura no campo da estética, ele é, certamente, menos competente do que o filósofo; ele poderia fazer melhor ao simplesmente expor, para a informação do filósofo, os dados de sua própria introspecção. Em suma, o que o poeta escreve sobre poesia deve ser estimado em relação à poesia que ele escreve (ELLIOT, 1972, p. 44).

Tomei gosto pela literatura através da poesia. Se não me engano, foi a partir dos versos de "Canção do Exilio", de Gonçalves Dias. O motivo foi algo que me encanta até hoje: ritmo. O ritmo dos payadores, dos sonetos de Vinícius, até dos parnasianos (que nunca odiei, apesar do esforço dos professores do Ensino Médio).

Naquela época, passei a esboçar alguns poemas. Todos para alguma paixonite de momento. Muito sentimentalismo e pouca técnica. Forçava rimas e não pensava em métrica. Parece incoerente: embora o ritmo me agradasse tanto, eu pouco me importava com a métrica. Provavelmente, as noções rítmicas ainda não fossem claras para mim.

O fato é que só passei a compreender melhor após ouvir o professor recitando o "Trem de Ferro", de Manuel Bandeira. E mais: foi quando percebi que unindo palavras era possivel imitar sons do ambiente. E não apenas os sons, mas também os ritmos.

Apesar da idolatria por Manuel Bandeira, eu acabei me afastando da poesia. Comecei a escrever contos e os poemas passaram ao segundo plano. Ultimamente, voltei a escrever poemas e, pela primeira vez, procuro trabalhá-los esteticamente. "Onda de pampa", foi o primeiro poema em que busquei me ater ao ritmo. E, aqui, volto a Manuel Bandeira e ao seu "Trem de Ferro". Buscava a unidade entre conteúdo e forma, nos moldes do que Bandeira fez em seu poema. Não tive a intenção de privilegiar uma característica ou outra, mas a conjunção. Outra vez, Elliot resume minha ideia:

Meu propósito aqui é insistir em que um poema
musical é um poema que possui um esquema
musical de som e um esquema musical dos
significados secundários das palavras que o
compõem, e no qual esses dois esquemas são
unos e indissolúveis. E se alguém objetar que
é apenas ao som puro, separado do sentido
que se pode com justeza aplicar o adjetivo
musical, apenas posso reafirmar minha prévia
declaração de que o som de um poema é uma
abstração tão grande do poema como o é o
sentido (ELLIOT, 1972, p. 53).

Assim, apresento o poema intitulado "Onda de pampa":

longa

onda

de canto

pelo

mar pampa 


boca
em boca
mate
mais mate
lida
após lida
dia
após dia
Vida
(que vida?)
trilha
de ida
triste
sofrida
longa
mui longa
sina
milonga
onda
de canto
pelo
mar pampa

Talvez não fique claro em um primeiro momento, mas a intenção foi criar o ritmo de uma milonga. Aliás, o título inicial era "Milonga" e o poema terminava em "[...] longa / mui longa / sina / milonga". Entretanto, o título anunciando a intenção eliminava a descoberta do ritmo ao longo da leitura. Para compreendê-lo melhor, é evidente que precisamos conhecer o ritmo da milonga arpejada em violão. Milonga é um ritmo típico do Pampa e - a seguir voltarei a esse assunto - parece carregar em si a planície de onde surgiu. Em geral, é arpejada em violão de maneira monótona e ondulante. É um ritmo quaternário e inicia com uma nota grave em suspensão que, alternando arpejos, será retomada ao fim do compasso, após um tempo final mais curto. Esse tempo final mais curto e a retomada instantânea da primeira nota em suspensão dá a impressão de que essa primeira nota é precedida por notas que, na verdade, não existem. Assim, a solução encontrada no poema, foi começar pela palavra "longa", que, completa o sentido da frase em sequência, mas, também. faz parte da palavra "milonga". Dessa forma, ao chegarmos aos últimos versos, a repetição do início nos faz preencher a lacuna da primeira palavra em suspensão e continuar o ciclo.

Mas, como citei anteriormente, a milonga, para mim, vai além do ritmo. Ela me desperta um estado sinestésico. Eu a vejo como a sintese musical do que é o Pampa: longa, levemente ondulante, cíclica, monótona. E não sou o único a pensar assim. Para explicar, contarei uma breve história:

Viajava pelo interior do Rio Grande do Sul e, pela janela do ônibus, eu via a confusão geográfica da serra se acalmar aos poucos, até se tornar uma planície infinita, levemente ondulante. A figueira que disputara a luz amarelada do sol do outono no paredão ingreme dos morros do Norte agora padecia solitária em campo aberto. Ouvi um acorde menor. A milonga era arpejada em violão e a voz, suave. Percebi a harmonia entre ritmo e espaço. E me dei conta de algo: a milonga não só fala do Pampa; pertence a ele.

Eu sempre reconheci lugares em ritmos. Não apenas a milonga é do Pampa: a salsa é do Caribe; o rap, do subúrbio. A milonga que ouvia naquela tarde se chamava "Milonga de sete cidades". O intérprete, um músico de Pelotas - uma cidade nos limites do Pampa e da planície litorânea do Rio Grande do Sul: Vitor Ramil.

O caminho e a milonga seguiam longamente. As sete cidades da canção tinham nomes: Rigor, Profundidade, Clareza, Concisão, Pureza, Leveza e Melancolia. Só depois descobri: essas "cidades" eram, para Vitor, as propriedades da milonga e daquilo que ele chamou de "estética do frio".

Vitor Ramil (2004) conseguiu, em seu ensaio "A estética do frio", traduzir o que eu sinto ao ouvir uma milonga. $E$, atualmente, me empenho em tentar fazer a literatura traduzir o mesmo sentimento que a milonga desperta em mim. Poderia despertar, com palavras, um sentimento de planície? A minha intenção com "Onda de pampa" foi essa. Mas a sinestesia não é só minha - e aqui abro um parêntese para contar uma história que passou comigo em 2012.

Passei pouco menos de um semestre em Córdoba, na Argentina, naquele ano. Muito do 
que eu defendo hoje foi influenciado por aquele período, em uma cidade nos limites do pampa argentino. Naquela época, a música estava mais presente na minha vida do que a literatura. E aqui lembro: não sou músico; no máximo, um amador com noções básicas e interesse pelo folclore argentino. De qualquer maneira, tocar violão era um hábito cotidiano. Durante uma roda com amigos, eu tocava uma zamba do uruguaio Jorge Drexler. Zamba é um ritmo de origens centenárias e incertas. Em todo caso, a zamba é muito popular no Norte argentino. Quando acabei a música, um amigo de Jujuy me olhou e disse: "qué llana esta zamba". Eu concordei e as músicas seguiram. Mas aquele comentário permaneceu me inquietando. Aquela zamba era realmente plana. E, por mais incertas que sejam as origens geográficas do ritmo, sua tradição deriva de um ambiente montanhoso. É claro que há zambas compostas na planície. Mas a estranheza do meu amigo de Jujuy (repito a cidade porque é importante para compreender a interpretação dele), ao ouvir aquela zamba llana demonstra justamente o caráter excepcional da música em questão. Há vários motivos que podem tê-lo levado àquela conclusão. Quem sabe por ser composta por um uruguaio; ou por ser interpretada por mim. Sem dúvidas, havia muito mais da planície em mim do que nele. De alguma maneira, isso ficou evidente de maneira semelhante ao que acontece comigo ao ouvir uma milonga.

Em uma conferência ministrada por Paul Valéry, na Oxford University, o poeta relata o momento, durante uma caminhada, em que um ritmo se impôs a ele, "como se alguém estivesse usando minha máquina de viver" (VALÉRY, 1991, p. 206. grifo do autor):

Um outro ritmo veio então reforçar o primeiro, combinando-se com ele; e estabeleceram-se não sei que relações transversais entre essas duas leis (estou explicando da maneira que posso). Isso estava combinando com o movimento de minhas pernas andando e não sei que canto que eu murmurava, ou melhor, que se murmurava através de mim. Essa composição se tornou cada vez mais complicada e logo ultrapassou em complexidade tudo o que eu podia produzir racionalmente de acordo com minhas faculdades ritmicas comuns e utilizáveis. Nesse momento, a sensação de estranheza da qual falei tornou-se quase penosa, quase inquietante. Não sou músico; ignoro totalmente a técnica musical; e eis que estava preso por um desenvolvimento de diversas partes, de uma complicação com a qual nenhum poeta sonhou algum dia. Dizia-me então que havia erro de pessoa, que essa graça enganava-se de cabeça, já que eu nada podia fazer com esse dom - que, em um músico, teria sem dúvida tomado valor, forma e duração, enquanto essas partes, que se misturavam e desligavam-se, ofereciam-me inutilmente uma produção, cuja continuação culta e organizada maravilhava e desesperava minha ignorância (VALÉRY, 1991, p. 206-207).

Não tenho dúvidas - e, fica claro, que tampouco Valéry - que o poeta experimentou um daqueles estímulos de que Reyes² trata como "uma poção mágica que tem sido chamada de inspiração" (2001, p. 69). Mas discordo de Valéry em um ponto: não houve erro de pessoa. Mesmo que Valéry ignorasse a técnica musical, ele havia reconhecido aquele ritmo complexo. E reconhecer o ritmo já faz parte de uma percepção intelectual. O poeta já estava interpretando o estímulo. Mas acreditar que o ritmo só poderia resultar em música talvez tenha sido determinante.

Para Yeats, o impulso criativo é fruto dos momentos de contemplação dos solitários (1994, p. 34). É a contemplação que permite que o poeta teça e desteça o mundo. E para Yeats, o ritmo tem o poder de prolongar o momento de contemplação:

[...] aquele em que estamos ao mesmo tempo despertos e adormecidos, que é o único momento de criação, ninando-nos com uma monotonia encantadora, enquanto nos leva a despertar pela variedade, para nos manter em um estado de verdadeiro transe, no qual a mente liberada da pressão e da vontade se manifesta em símbolo (YEATS, 1994, p. 34, tradução nossa). ${ }^{3}$

É esse estado meditativo que busco com meus poemas. O estado meditativo causado pelas milongas de Vitor Ramil (o estado que relatei há

\footnotetext{
2 Alfonso Reyes (apud Nieto, 2001, p. 69) lista 12 "estímulos", os quais Nieto acredita comporem "a fórmula desta poção mágica que tem sido chamada de inspiração". São estimulos literários, verbais, visuais, auditivos, de sentidos inferiores (olfativo, gustativo, tátil), ambulatoriais, oníricos, da memória involuntária, sinestésicos, físicos, emotivos e provocados voluntariamente.

3 Do original: [...] aquel en que estamos a un tiempo despiertos y dormidos, que es el único momento de creación, acunándonos con una monotonia encantadora, mientras nos lleva a despertar por la variedad para mantenernos en un estado de verdadero trance, en el que la mente liberada de la presión de la voluntad se manifiesta en símbolo.
} 
pouco, sentado na poltrona de um ônibus, não é diferente do estado que Yeats defende). Dessa forma, alcançar uma literatura llana, como uma planície levemente ondulada, é o primeiro passo para transmitir esse mesmo estado ao leitor; mas através da palavra.

Yeats ainda defende uma mudança na poesia:

Com esta mudança de substância, com este retorno à imaginação, entendendo que as leis da arte, que são as ocultas leis do mundo, só poderiam limitar a imaginação, poderia ocorrer uma mudança de estilo e poderiamos nos livrar dessa poesia séria de ritmos enérgicos semelhantes a um homem que corre, que é a invenção da vontade sempre com seus olhos postos sobre algo a fazer ou desfazer; e poderíamos extrair esses ritmos ondulantes, meditativos, orgânicos, que são a estrutura da nossa imaginação, que nem deseja nem odeia, porque é feita de tempo, e apenas quer observar alguma realidade, alguma beleza (YEATS, 1994, p. 36, tradução nossa). ${ }^{4}$

A poesia defendida por ele é aquela feita da mesma matéria que a imagem do Pampa, que a milonga. Para entender, no entanto, é preciso definir alguns conceitos - todos parte de uma poética própria, mas indispensáveis para qualquer análise.

\section{Algumas definições}

Em primeiro lugar, o que é o Pampa? Ou melhor: o que eu entendo como Pampa?

Sabe-se que o Pampa não se resume à porção brasileira do bioma. Tanto o Uruguai quanto a Argentina compartilham esse espaço conosco. Até aqui acredito não haja discordâncias. Se pensarmos no Rio Grande do Sul, o Pampa ocuparia grosso modo, a metade Sul do estado, iniciando a partir uma linha imaginária situada em torno do paralelo $30^{\circ}$ Sul, com algumas "ilhas" avançando ao Norte desse traçado.

O Pampa argentino é ainda mais complicado de se delinear. De maneira geral, trata-se de uma zona situada ao redor do Rio da Prata, que se estende desde a provincia de La Pampa, a província mais austral do bioma em conjunto com Buenos Aires, seguindo ao Nordeste argentino, até Corrientes. Segundo Elena M. Rojas, ${ }^{5}$ o Pampa argentino é uma "vasta planície que se estende ao longo da parte central da Argentina, desde a costa do Atlântico até o sopé dos Andes, e desde o Grande Chaco (ao Norte) à Patagônia (ao Sul)" (ROJAS, 1996, p. 299, tradução nossa). ${ }^{6}$

Talvez o único consenso se refira às terras uruguaias, geralmente classificadas como Pampa em sua totalidade. Esse bioma compartilhado pelos três países é caracterizado por ser uma região de planícies e coxilhas, com vegetação rasteira, sem cadeias montanhosas ou florestas contínuas.

Mas seria ingênuo pensar o Pampa apenas a partir dos aspectos geográficos que o caracterizam. Há diversos sistemas que se inter-relacionam quando falamos dele. Martínez Estrada (1996), por exemplo, utiliza a palavra pampa de uma forma que extrapola os limites da llanura - e, assim, podemos entender la pampa do autor como metonímia da própria Argentina. É preciso levar em conta o imaginário, inseparável do lugar e que se difunde para além de suas fronteiras. Pois, se é plausivel localizar geograficamente o Pampa no Rio Grande do Sul, é impossivel determinar um início e um fim para o imaginário que diz respeito a esse lugar.

Portanto, só podemos evocar a imagem do Pampa se, junto a ela, evocarmos a imagem das pessoas que nele habitam: gaúchas. Eé interessante notar que a palavra gaúcho, como a entendemos hoje no Rio Grande do Sul, tornando-se gentilico do estado, de alguma maneira corrobora com as diferenças que faço entre o Pampa geográfico e o Pampa imaginário. Pensemos em uma pessoa que imaginamos como gaúcha stricto sensu: habitante do Pampa, oriunda da mistura entre variadas etnias,

\footnotetext{
4 Do original: Con este cambio de sustancia, con este retorno a la imaginación, entendiendo que las leyes del arte, que son las ocultas leyes del mundo, sólo podrian limitar la imaginación, podría darse un cambio de estilo, y podriamos deshacernos de esa poesía seria de ritmos enérgicos semejantes a un hombre que corre, que es la invención de la voluntad siempre con sus ojos puestos sobre algo a hacer o deshacer; y podriamos extraer esos ritmos ondulantes, meditativos, orgánicos, que son la estructura de nuestra imaginación, que ni desea ni odia, porque está hecha de tiempo, y solamente quiere observar alguna realidad, alguna belleza.

5 O verbete faz parte do glossário organizado por Rojas, presente na edição crítica da obra Radiografía de la pampa, de Ezequiel Martínez Estrada (1996).

6 Do original: Vasta llanura que se extiende a lo largo de la parte central de la Argentina, desde la costa del Atlántico hasta las estribaciones de los Andes, y desde el Gran Chaco (al norte) a la Patagonia (al Sur).
} 
de vida campeira. É como se essas definições rompessem os limites, abrangendo todos os demais habitantes, para os quais o imaginário está presente de forma mais ou menos intensa.

Ao refletir sobre essas questões desde a perspectiva literária, e, em especial, pensando a poesia presente nos sistemas relacionados ao Pampa, chego a algumas considerações. A primeira diz respeito à tradição oral dos versos gauchescos; além disso, há um forte laço entre poesia e música.

Para Guilhermino Cesar, a poesia gauchesca procede do Cancioneiro (2006, p. 203). Ainda, afirma que manifestações parecidas surgiram na mesma época na Argentina e Uruguai. No entanto, as motivações não seriam as mesmas, já que os modelos do Rio Grande do Sul foram estimulados por correntes de autores do Norte brasileiro (2006, p. 204). Porém, acredito que as conexões sejam mais complexas. Afinal, o que entendo como poesia não se resume à poesia escrita. Certamente, houve muitos versos anônimos, improvisados oralmente (que talvez tenham sido criados por poetas analfabetos), oriundos de trovas e desafios. Me parece precoce a ideia de dar as costas à possibilidade de um intercâmbio poético para além dos limites do Pampa brasileiro.

E pensando nessa confluência, chego ao modelo que talvez seja mais exemplar para o que pretendo tratar: a payada. O formato é emblemático por dois motivos. Primeiro, por estar presente nos três paises; segundo, por seguir o mesmo padrão - versos em décimas espinelas (ou estrofes derivadas desse modelo, como a sextilha ou a oitava), acompanhados pelo ritmo de milonga.

Não parece haver discordância quanto à origem da décima espinela. Ela deve seu nome ao poeta espanhol Vicente Espinel, o primeiro a se dedicar a décimas seguindo o modelo de rimas $A-B-B-A-A-C-C-D-D-C$, com versos heptassilábicos (octossilábicos em espanhol). Segundo Maximiano Trapero (2008), as primeiras décimas espinelas foram publicadas em 1591, na obra Diversas Rimas. O tema foi citado pelo cantor uruguaio Jorge Drexler, em uma conferência divulgada no canal TED Talks. Sobre Espinel, Drexler afirma: "foi o mesmo que pôs a sexta corda àquela que depois seria a guitarra espanhola7" (DREXLER, 2017, tradução nossa).

Na mesma conferência, Drexler reflete sobre sua identidade uruguaia e chega ao mesmo ponto de Vitor Ramil (2004) em seu ensaio A estética do frio. Para ambos, a milonga seria o ritmo mais simbólico, tanto ao Pampa de Vitor Ramil quanto ao Uruguai de Drexler. No entanto, este último procura desconstruir a ideia de origem da milonga, fazendo um percurso histórico não linear do ritmo, pontuando suas transformações, sua mestiçagem, numa circularidade espaço-temporal, que abrange praticamente todos os continentes.

Mas o que é a milonga? Ou: qual é a milonga sobre a qual me refiro? Inegavelmente, trata-se de um gênero musical típico do meio pampeano. Retomando o que já foi abordado enquanto analisava a escrita do poema "Onda de pampa", a milonga geralmente é ponteada em violão de maneira monótona e ondulante. Um ritmo quaternário que intercala bordoneios e arpejos. A milonga tem, tradicionalmente, um acento peculiar, que se identifica por três marcações graves, a última delas com a duração menor, como se fizesse parte do início do compasso seguinte.

Segundo Vitor Ramil (2004), há dois tipos de milonga, a "alegre", "para dançar", e a "pampeana" ou "campeira",

$$
\begin{aligned}
& \text { simples e monótona, segundo a definição de } \\
& \text { um dicionário; lenta, repetitiva, emocional; } \\
& \text { afeita à melancolia, à densidade, à reflexão; } \\
& \text { apropriada tanto aos vôos [sic] épicos como } \\
& \text { aos líricos, tanto à tensão como à suavidade, } \\
& \text { e cuja espinha dorsal são o violão e a voz } \\
& \text { (RAMIL, 2004, p. 22). }
\end{aligned}
$$

É essa "segunda" milonga à qual nos referimos quando falamos em payada. Feitos esses esclarecimentos, continuemos a pensar na relação entre poesia e música a partir de algo indispensável à payada: a oralidade.

\footnotetext{
Parece haver um equivoco com relação a essa informação. Trata-se não da sexta corda, mas da quinta (antes a guitarra costumava ter apenas quatro cordas). Segundo Maria Isabel Osuna Lucena (1991), tampouco há consenso sobre essa afirmação, pois, apesar de Espinel ser famoso pela suposta adição da quinta corda, a autora lembra que "já existiam guitarras de cinco cordas antes do seu nascimento" (1991, p. 147, tradução nossa).
} 


\section{Ritmo e oralidade}

Elliot (1972) acredita que a musicalidade da poesia se dá quando há um "retorno ao falar comum": "Nenhuma poesia, naturalmente, é jamais o mesmo linguajar que o poeta usa ao falar ou que escuta, mas deve estar numa tal relação com o dialeto de sua época que o ouvinte ou o leitor possam dizer: 'Assim é que eu falaria se falasse em verso'" (ELLIOT, 1972, p. 50).

Octavio Paz (2012) concorda. Para ele, "a linguagem falada está mais perto da poesia que da prosa; é menos reflexiva e mais natural, e por isso é mais fácil ser poeta sem sabê-la que prosador" (PAZ, 2012, p. 29).

Essa busca pela oralidade me faz voltar ao Pampa. Não é só de arpejos em violão que é feita a milonga. Há versos. Há formas e improvisos. E, claro, oralidade. Falo aqui das payadas. Formato poético característico de nossa planície, em geralé acompanhada pelas milongas. A forma tradicional da payada é a estrofe de dez versos - a décima -, mas também há variações: com oito versos ou com seis - a sestina, ou sextilha, do Martín Fierro. A estrutura das rimas, porém, é mantida: nos formatos "reduzidos" - assim chamemos - são suprimidos os primeiros versos da décima.

Se, por exemplo, pensarmos na payada "tradicional", por consequência, na décima, podese sugerir que foi Vicente Espinel quem primeiro configurou o modelo de estrofes e rimas que seguem o mesmo padrão ainda hoje. Entretanto, a décima espinela se difundiu por praticamente todo o território latino-americano, o que impossibilita que se caracterize estruturalmente como uma forma de poesia restrita ao Pampa. Porém, fica nítido que a décima tenha adquirido as caracteristicas do ambiente platino e pampeano - e então, talvez, possamos passar a chamá-la de payada. Mas essas transformações vão além dos temas puramente literários, uma vez que a payada se consolidou como um tipo de arte composta: é poesia, mas também é música.

Um fator a se levar em conta, ainda, é a que Borges (1997) discute no ensaio "La poesía gauchesca". Até que ponto essa literatura foi obra de gauchos? A sua consolidação, em grande parte, não se deu a partir do intelecto urbano? O autor argentino afirma: "Não menos necessário para a formação desse gênero do que o Pampa e as coxilhas foi o caráter urbano de Buenos Aires e Montevidéu" (1997, p. 179, tradução nossa). ${ }^{8}$ É discutivel, assim, a afirmativa de que a payada ou qualquer outro gênero "gauchesco" sejam manifestações estritamente rurais. É inegável que seus versos remetem à lida do gaúcho campesino, mas quantos dos payadores foram realmente esses gaúchos? Vale lembrar que a payada não se constituiu tão-somente no meio oral, de cunho desafiador, produzida no campo. Mas é obra, também, de autores que a planejaram para a palavra escrita. Autores que, de alguma maneira, se alinharam a uma tradição, que talvez não existisse para além de uma mitologia. São estes os payadores que tiveram mais reconhecimento, e é essa "tradição" do urbano que se volta ao mito ancestral que a mantém ainda em voga.

Pensemos, por exemplo, em dois cantores criados longe do meio rural, como o pelotense Vitor Ramil e o montevideano Jorge Drexler. Em ambos, não há quase nenhum traço de criollismo empírico. Não se trata de homens do campo, de tropeiros, peões de estância. Isso, entretanto, não os impede de cantar décimas, de retomar os payadores. Não são exemplos do gaúcho ancestral e mitificado (e será ele que existiu?). Mas não são alheios ao imaginário dessa cultura. E, como parte desse imaginário, contribuem para a constante e infinita reformulação dele. Considerando isso, é impossivel a tarefa de tratar a poesia pampeana de uma forma cronológica. Pois os múltiplos sistemas que envolvem o tema Pampa estão conectados ao imaginário. E o imaginário se atualiza conforme nos apropriamos dele. Quero dizer: o gaúcho do mito assim o é em um tempo instantâneo, imutável, o que não existe no imaginário, que é mutável. Não há como definirmos o marco histórico do mito, já que haveria tantos marcos quanto pessoas que se apropriassem dele. Assim,

8 Do original: No menos necesario para la formación de ese género que la pampa y que las cuchillas fue el carácter urbano de Buenos Aires y Montevideo. 
ele só pode ser pensado no presente, em eterna reconstrução. Ou, como bem lembra Finazzi-Agrò ao discorrer sobre o "caráter nacional" na literatura brasileira, de que ele

depende não de um futuro a ser edificado nem de um passado a ser cultuado, mas de um passado que parece não passar e de um presente incerto e difuso no qual impera o arbítrio, a reconstrução subjetiva dos fatos, a aleatoriedade de uma memória sem resgate (2013, p. 64).

Mas voltemos à musicalidade.

Quando Elliot (1972, p. 57) fala que ela não está em cada linha do poema, mas no conjunto, a payada é um bom exemplo. Não há inovações estéticas, figuras de linguagem ou de som. Tratase de uma forma relacionada à oralidade e ao improviso. Mas o conjunto dos versos tem um ritmo próprio. Talvez o esquema das rimas, talvez a métrica em redondilha maior. Não chego a uma conclusão, mas há algo, nas payadas, que me fazem viajar ao Pampa, a um lugar ancestral.

Aqui me pongo a cantar

Al compás de la vigüela,

Que el hombre que lo desvela

Una pena estrordinaria

Como la ave solitaria

Con el cantar se consuela (HERNÁNDEZ, 2001, p. 99).

"A poesia não passa de tempo, ritmo perpetuamente criador", diz Octavio Paz (2012, p. 34). Talvez seja essa caracteristica que me faça reconhecer nos versos acima esse lugar ancestral. Talvez seja o retorno do mito. É o que Octavio Paz defende: ritmo é rito e mito:

A data mítica não morre: repete-se, encarna. Então, o que distingue o tempo mítico de todas as outras representações do tempo é o fato de ser um arquétipo. Passado sempre suscetivel de ser hoje, o mito é uma realidade flutuante, sempre disposta a encarnar-se e voltar a ser (PAZ, 2012, p. 70).

Assim, é através da repetição ritmica que o mito retorna. Essa constatação me leva a crer que é inevitável não pensar no mito do gaucho. E, embora o gaúcho nunca tenha sido o que o imaginário nos propõe, é o mito que permanece. E é provável que ele tenha acontecido nos tempos dos primeiros payadores. Ao resgatar a forma da décima, retornavam a mitos anteriores. Eis o ciclo da poesia: "ritmo perpetuamente criador".

E é inegável que há muito de épico na décima. E esse, junto com a oralidade, parece ser o caráter essencial da forma. Tanto que parece sobrar pouco espaço para o lírico. É o que acontece pelo menos comigo.

Há algum tempo, tento criar um poema em forma de décimas. Não busco uma payada, mas um poema lírico. Não preciso dizer que estou longe de conseguir algo esteticamente aceitável. É provável que me falte talento. Quanto a isso, Elliot diz: "em um soneto perfeito, o que se admira não é tanto a habilidade do autor em se adaptar aos padrões, mas muito mais a habilidade e o poder com que ele faz com que estes padrões se integrem com o que ele quer dizer" (1972, p. 58). Quem sabe seja isso: enquanto não tiver o que dizer, não importa o formato que escolha. No entanto, por diversas vezes, consegui criar décimas improvisadas, alheio a primores estéticos. E então retorno ao mote: é possivel dissociar a payada do falar comum? E talvez possamos ir além: é possivel dissociar a poesia do falar comum?

\section{Ritmo e idioma}

Em Esse oficio do verso, Borges comenta:

pediram-me que declamasse alguns versos meus; direi então um soneto, o soneto sobre Spinoza. O fato de muitos de vocês talvez não saberem espanhol o fará um soneto mais belo. Como disse, o sentido não importa - o que importa é uma certa música, um certo modo de dizer as coisas (BORGES, 2000, p. 125).

\section{Elliot não concordaria:}

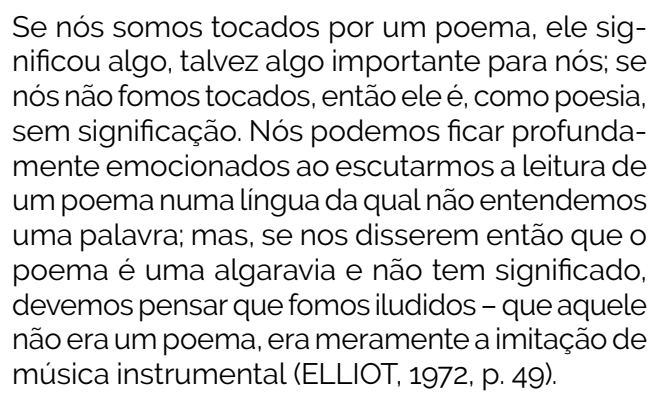


Obviamente, o poema lido por Borges não se encaixa na preocupação de Elliot: há um sentido no que se está declamando em uma língua desconhecida. Não acho que um poema possa não ter significado. Aliás, a simples musicalidade já contém um significado.

Mas, por vezes, nos vemos incapazes de dizer algo em nosso próprio idioma. Há algo em seu ritmo que não dá conta do que queremos expressar. Isso aconteceu comigo há pouco tempo. Viajava para o Uruguai e uma ideia surgiu. Talvez seja o formato que eu consegui fazer se aproximar mais de uma payada, apesar das inúmeras diferenças. Porém, em momento algum, durante a escrita, eu tive a intenção de escrever em português. O tema pedia outra língua. $O$ ritmo próprio do poema só poderia funcionar em castelhano. Eu não poderia explicar o mecanismo - e, no plano subjetivo no qual a criação se dá, acredito que ninguém possa. Afinal, acredito que devemos respeitar o poema: não falo em supervalorizar a inspiração ou confiar demais na escrita automática, mas, por vezes, o poema é exigente. Ir de encontro é fatal à poesia.

Vamos ao poema "De instante y eternidad":

En la Banda Oriental

paralelo treinta y tres

la ciudad de Treinta y Tres.

Alguien dijo que se nombra

en honor a aquellos hombres

treinta y tres orientales

que en la pampa festejaron

por la sangre de otros tantos.

Sobre el campo de batalla

de aquel tiempo, las tres cruces

donde, eterna en el retrato

hay la sangre de otro hombre.

Pero, al mismo u otro tiempo

que es instante y eternidad

en aquel otro oriente

treinta y tres grados al norte

al poeta no le importa

si tiene uno o treinta y tres

personajes la otra historia.

Hay apenas el momento

\author{
que será tres solos versos \\ en el que una hoja tridente \\ brota roja en una rama \\ para otra vez caerse \\ cuando regrese el otoño \\ y brotar una vez más \\ como le pasó tres veces \\ a aquel hombre con su cruz \\ antes que el rojo brotara \\ desde su carne desnuda \\ a las tres horas del dia \\ que era otoño y primavera \\ en el año treinta y tres.
}

Não é dificil perceber a referida semelhança com as payadas. Parte se deve ao tema, parte, à métrica. Há algum ritmo que remete às décimas. $\mathrm{E}$ algo disso se perde na tradução. Como exemplo, a tradução dos primeiros oito versos:
Sobre a Banda Oriental
paralelo trinta e três
a cidade Treinta y Tres.
Assim dizem que se chama
em tributo àqueles homens
trinta e três orientais
que no pampa festejaram
pelo sangue de outros tantos.

Há perdas importantes: a palavra "chama" no lugar de "nombra" deixa de lado a aproximação fonética com a palavra "hombres" do verso abaixo. A palavra "tributo", no lugar de "honor", mantém a métrica do verso - o que não aconteceria com "honra" -, mas também quebra o ritmo leve desses dois versos. "Alguien dijo que se nombra I en honor a aquellos hombres" é muito mais melódico do que "Assim dizem que se chama / em tributo àqueles homens".

Não há como explicar a necessidade de escrever em outra língua. Mas o caso desse poema é exemplar. Apesar de minha língua nativa ser o português, eu precisei ceder às exigências do poema. E, ao meu entender, na busca por uma literatura plana, esse poema tem muito mais de planicie em castelhano do que em português. 


\section{Considerações finais}

Não consigo pensar no fazer poético alheio ao ritmo. É minha maneira de ler poesia e, evidentemente, isso se transmite aos meus primeiros versos. A minha própria busca por uma literatura sinestésica me leva a ver o ritmo como um aliado.

Como defende Octavio Paz, o ritmo é a retomada dos mitos. Ritmo é ciclo. Ritmo é o tempo. Não por acaso, apresentei dois poemas que não só contêm um ritmo próprio, mas falam em ciclo, são ciclos. E foi um processo inconsciente - na verdade, apenas agora me dou conta disso. E talvez isso seja a prova da sobrevivência dos mitos: sem nos darmos conta, eles retornam, sem jamais terem ido embora.

\section{Referências}

BORGES, Jorge Luis. Esse ofício do verso. São Paulo: Cia das Letras, 2000.

BORGES, Jorge Luis. Obras completas. Buenos Aires: Emecé Editores,1997. v. 1

CESAR, Guilhermino. História da Literatura do Rio Grande do Sul (1737-1902). Porto Alegre: Instituto Estadual do Livro; Corag, 2006.

ELIOT, Thomas Stearns. Musicalidade da poesia. In: ELIOT, Thomas Stearns. A essência da poesia. Estudos e Ensaios. Rio de Janeiro: Artenova, 1972. p. 43-6o.

FINAZZI-AGRÒ, Ettore. Entretempos: mapeando a história da cultura brasileira. São Paulo: Editora Unesp, 2013.

HERNÁNDEZ, José. Martín Fierro: edición critica. 1. Ed. Coordenação de Élida Lois y Ángel Nuñez. Madrid: ALLCA XX, 2001.

MARTÍNEZ ESTRADA, Ezequiel. Radiografia de la pampa. Edición crítica. 2. ed.. Leo Pollmann, coordinador. Madrid: ALLCA XX, 1996

NIETO, Ramón. A inspiração. In: NIETO, Ramón. O ofício de escrever. São Paulo: Angra, 2001. p. 67-70.

OSUNA LUCENA, Maria Isabel. Sobre un "Latinista, poeta y músico..." llamado Vicente Espinel. Laboratorio de Arte: Revista del Departamento de Historia del Arte, Sevilla, n. 4, p. 129-148, 1991. Disponivel em: http:// institucional.us.es/revistas/arte/04/08\%200suna.pdf. Acesso em: 3 jul. 2017.

PAZ, Octavio. O arco e a lira. São Paulo: Cosac Naify, 2012.

POETRY, Music and identity | Jorge Drexler. [S. l.: s. n.], 2017. 1 video (16 min).

Publicado pelo canal TED: Technology, Entertainment and Design. Disponivel em: https://www.youtube.com/ watch? $v=C 2 p 42 G A S n \cup o$. Acesso em: 14 set. 2019.
RAMIL, Vitor. A estética do frio: conferência de Genebra. Pelotas: Satolep Livros, 2004. Disponivel em: https:// www vitorramil.com.br/d/Vitor\%20Ramil\%20-\%20A\%20 estetica\%20do\%20frio.pdf. Acesso em: 8 jun. 2021.

ROJAS, Elena M. Índice Onomástico, toponímico y glosario. In: MARTÍNEZ ESTRADA, Ezequiel. Radiografia de la pampa. Edición crítica. 2. ed. Coordenação de Leo Pollmann. Madrid: ALLCA XX, 1996. p. 259-315.

SCHMIDT, Siegfried J. Sobre a escrita de história da literatura. Observações de um ponto de vista construtivista. In: OLINTO, Heidrun Krieger. Histórias de literatura. As novas teorias alemãs. São Paulo: Ática, 1996. p. 101-131.

TRAPERO, Maximiano. Vicente Espinel, la décima espinela y lo que de ellos dicen los decimistas. In: VI Encuentro-Festival Iberoamericano de la Décima y el Verso improvisado. 1., 2000, Las Palmas. Actas [...]. Las Palmas: Estudios, 2000. p. 117-137. Disponivel em: http://www.serraniavirtual.com/download/pdf/Vicente_Espinel\%20la\%20decima\%20espinela\%20y\%20 lo\%20que\%20de\%20ellos.pdf. Acesso em: 3 jul. 2017.

VALÉRY, Paul. Poesia e pensamento abstrato. In: VALÉRY, Paul. Variedades. São Paulo: Iluminuras, 1991. p. 201-218.

YEATS, William Butler. El simbolismo de la poesía. In: Cómo se escribe un poema. Argentina: El Ateneo. 1994. p. 29-37.

\section{Gabriel Eduardo Bortulini}

Doutor em Letras, na área de concentração em Escrita Criativa pela Pontifícia Universidade Católica do Rio Grande do Sul (PUCRS), em Porto Alegre, RS, Brasil.

\section{Endereço para correspondência}

Gabriel Eduardo Bortulini

Pontifícia Universidade Católica do Rio Grande do Sul Av. Ipiranga, 6.681, Prédio 8, sala 403

Partenon, 97010-082

Porto Alegre, RS, Brasil

Os textos deste artigo foram revisados pela Poá Comunicação e submetidos para validação do autor antes da publicação. 